DOI: 10.46340/eujem.2021.7.2.7

\author{
Olena Lahovska, ScD in Economics \\ ORCID ID: https://orcid.org/0000-0001-9517-0499 \\ Zhytomyr Polytechnic State University, Ukraine \\ Habriella Loskorikh \\ ORCID ID: https://orcid.org/0000-0002-5402-7220 \\ Zhytomyr Polytechnic State University, Ukraine
}

\title{
ACCOUNTING FOR SOFTWARE DEVELOPMENT OPERATIONS IN IT-ENTERPRISES: AREAS FOR IMPROVEMENT
}

\author{
Олена Лаговська, д. е. н. \\ Габріела Лоскоріх \\ Державний університет "Житомирська політехніка», Україна
}

\section{ОБЛІКОВЕ ВІДОБРАЖЕННЯ ОПЕРАЦІЙ 3 РОЗРОБКИ ПРОГРАМНОГО ЗАБЕЗПЕЧЕННЯ В ІТ-ПІДПРИЕМСТВАХ: НАПРЯМИ УДОСКОНАЛЕННЯ}

The purpose of the study is to identify areas for improvement of accounting operations with software to create appropriate information support for the management of IT enterprises. To achieve this goal, the following scientific objectives are identified: to evaluate the options for accounting software, to analyze scientific papers on certain stages of software development in the IT-enterprise, to improve information support of the software development management process in the IT-enterprise. The relevance of the study is due to the rapid development of IT in many countries around the world, including Ukraine. Effective management of IT enterprises requires special attention to accounting as the main source of information. The following methods were used to solve the tasks: analysis and synthesis, logical generalization, comparative comparison, graphical method. The article pays attention to the accounting of software development operations as one of the main aspects in IT-enterprises. The options of accounting software (as an object of fixed assets, intangible assets, royalties, expenses of the period), as well as generalization of the order of accounting for income and expenses of the IT company (when transferring development software) depend on the wording of the contract. The process of software development management in the IT-enterprise is reflected on the basis of accounting information, which allowed to determine the necessary analytical sections of costs (orders, development stages) incurred during this process, and justify the management as a basis for the allocation of the time required to implement each IT project. The implementation of these proposals will facilitate the prompt calculation of the payback of the IT-project, facilitate the processing of credentials and the construction of management reporting.

Keywords: software, costs, intangible assets, IT-company, accounting.

Постановка проблеми. Діяльність підприємств в сфері інформаційних технологій (IT) охоплює такі їі види, як розробка програмного забезпечення та сервісів на його основі, надання ITпослуг (проектування, впровадження, тестування інформаційних систем тощо), розробка програмноапаратних комплексів. У 2020 році порівняно з попереднім роком експорт IT-індустрії зріс на 20,4 \% або на 853 млн. дол. США ${ }^{1}$. Для забезпечення ефективності діяльності підприємств IT-сфери,

\footnotetext{
${ }^{1}$ Результати аналізу у «Офісі ефективного регулювання» BRDO (2021). IT-ексnорm y 2020.

За даними НБУ щзодо платіжного балансу $і$ зовнішньої торгівлі

$<$ https://brdo.com.ua/wp-content/uploads/2021/02/IT-eksport-u-2020-2.pdf> (2021, березень, 15)
} 
збереження конкурентних переваг необхідним є удосконалення методики бухгалтерського обліку, який забезпечує інформаційну складову в процесі прийняття управлінських рішень.

Учасниками надання IT-послуг можуть бути: вендори (займаються розробкою програмного забезпечення); реселлер (встановлюють та обслуговують обладнання та програмне забезпечення); дистриб'ютори (виконують обов'язки з постачання обладнання або носія програмного забезпечення реселлеру та сервісу); споживачі. Враховуючи, що основним видом діяльності IT-підприємств $є$ все ж таки розробка програмного забезпечення, доцільним є розкриття облікового відображення цих операцій у вендорів.

Аналіз основних досліджень і публікацій. Незважаючи на стрімкий розвиток IT-індустрій, наукові дослідження, присвячені питанням бухгалтерського обліку програмного забезпечення на підприємствах даної сфери, практично відсутні. Особливості обліку створення програмного забезпечення піднімали в своїх працях О.В. Перчук, І.В. Первій, Ю.М. Попівняк, Ю.С. Серпенінова. Проте тільки І.В. Первій наголосила на важливості «...розмежування критеріїв капіталізації витрат на дослідження та розробки в розрізі підприємств, які створюють комп'ютерні програми для власного використання, та спеціалізованих IT-компаній, що спеціалізуються на їх розробці та займаються їх постійною реалізацією на сторону» ${ }^{1}$. Проведений огляд літературних джерел підтверджує актуальність дослідження та вказує на необхідність вивчення праць науковців, які б дозволили визначити особливості розробки програмного забезпечення для подальшого їх врахування в управлінні даним процесом.

Формулювання цілей статті. Основною метою $є$ визначення напрямів удосконалення обліку операцій 3 програмним забезпеченням для створення належного інформаційного забезпечення управління діяльністю IT-підприємства.

Опис основного матеріалу дослідження. Продукти та технології, які створює IT-підприємство, як правило, представляють собою програмне забезпечення. Саме воно, будучи одним з основних об'єктів бухгалтерського обліку на IT-підприємствах, може виступати в обліку в декількох ролях (рис. 1).

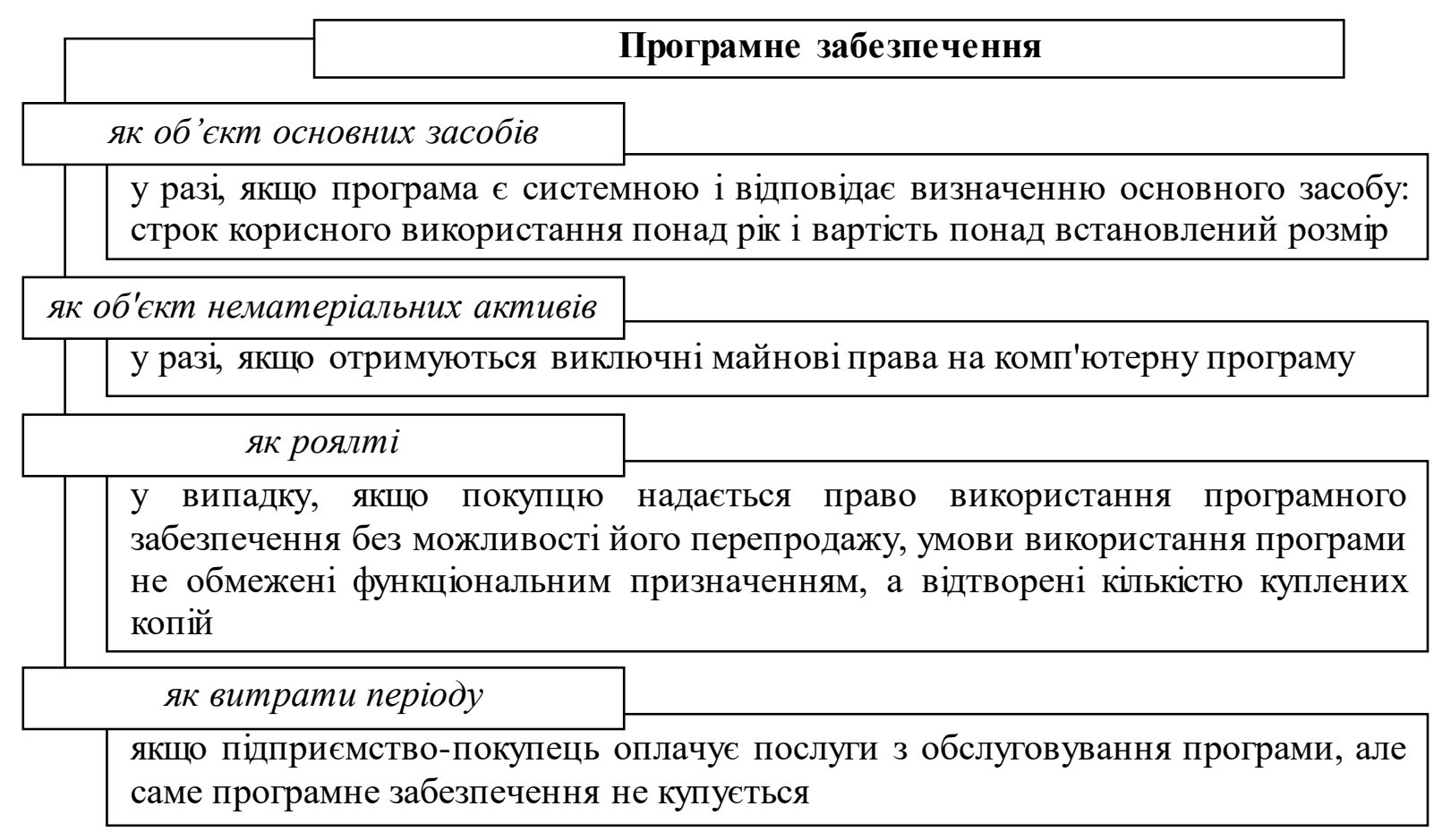

Рис. 1. Варіанти бухгалтерського обліку програмного забезпечення

Джерело: узагальнено та доповнено на основі ${ }^{2}$

\footnotetext{
${ }^{1}$ Первій, I. В. (2014). Аналіз сучасних проблем обліково-аналітичного забезпечення створення комп'ютерних програм. Проблеми теорії та методології бухгалтерського обліку, контролю і аналізу, 3, 277-289.

${ }^{2}$ Там само.
} 
Описані вище варіанти бухгалтерського обліку програмного забезпечення (рис. 1) стосуються, насамперед, особливостей обліку вже розробленого та придбаного програмного забезпечення. Ці варіанти можуть застосовуватися на IT-підприємстві, оскільки можливим є варіанти використання не тільки власне розробленого, але й придбаного програмного забезпечення. Крім того, можливою $\epsilon$ ситуація, коли IT-підприємство розроблює програмне забезпечення з метою подальшого продажу прав на його використання або розтиражованих копій. Передбачається, що IT-підприємство має право тиражувати, продавати, здавати в оренду, перешкоджати неправомірному використанню програмного забезпечення. В такому випадку за умови дотримання вимог П(С)БО 8 «Нематеріальні активи» програмне забезпечення визнається нематеріальним активом на субрахунку 125 «Авторське право та суміжні з ним права» 3 перенесенням суми витрат, накопичених на субрахунку 154 «Придбання (створення) нематеріальних активів».

Проте для правильного віднесення витрат, попереднього необхідним є визначення етапів розробки програмного забезпечення, окреслимо його життєвого циклу. Дане поняття є базовим в сфері програмної інженерії та трактується, як зазначає Вендров А.М. ${ }^{1}$, як «період часу, який починається з моменту прийняття рішення про необхідність створення програмного забезпечення i закінчується в момент його повного вилучення з експлуатації».

Основним нормативним документом, який регламентує склад життєвого циклу, є міжнародний стандарт ISO / IEC / IEEE 12207: 2017 «Systems and software engineering - Software life cycle processes» ${ }^{2}$. Відповідно до цього стандарту до складу життєвого циклу програмного забезпечення включають чотири групи процесів, зокрема:

- процеси узгодження (придбання, постачання);

- організаційні процеси, що сприяють проекту (управління моделлю життєвого циклу, управління інфраструктурою, управління портфелем, управління людськими ресурсами, управління якістю і управління знаннями);

- процеси технічного управління (планування проекту; оцінка та контроль проекту; управління рішеннями; управління ризиками; управління конфігурацією; управління інформацією; вимірювання; гарантія якості);

- технічні процеси (аналіз бізнесу або місії; визначення потреб та вимог зацікавлених сторін; визначення вимог до систем / програмного забезпечення; визначення архітектури; визначення дизайну; системний аналіз; впровадження; інтеграція; верифікація; перехід; перевірка; операція; технічне обслуговування; утилізація).

Проте на відміну від попередніх версій, в даному стандарті не передбачено конкретної моделі життєвого циклу програмного забезпечення та немає чітко затверджених етапів. Наведені процеси можуть здійснюватися на різних етапах - це буде залежати від конкретного проекту.

Незважаючи на затверджену в стандарті позицію, науковці намагаються навести власне бачення процесу розробки програмного продукту. Так, К.Е. Файзрахманова ${ }^{3}$ виділяє такі його рівні, як планування; призначення; розробки; контроля; зборки; оцінки та тестування; дослідної експлуатації; промислової експлуатації.

Підхід автора висуває ряд питань, адже відбуваються логічні порушення в частині виділення складових - назва процесу відповідає одному з рівнів. Крім того, розглядаючи рівень призначення, науковець визначає алгоритм планування (без конкретизації об'єкта планування), хоча рівень планування був розглянутий вище. В ході описання даного алгоритму виділені етапи, отже, в складі певного рівня можливим є окреслення послідовних дій. Таким чином, виникає питання що автор розуміє під поняттям «рівень» і його відношення до поняття «процес» та «етап». Виходячи з опису автором представлених рівнів, на нашу думку, кращим є використання поняття «етап».

Хоча і не можемо підтримати позицію науковця повною мірою, вважаємо за необхідне вказати на важливість деталізації процесу розробки. Адже представлення точних етапів необхідне

\footnotetext{
${ }^{1}$ Вендров, А. М. (2006). Проектирование программного обеспечения экономических информационных систем. Москва: Финансы и статистика, 39

2 ISO / IEC / IEEE 12207 (2017). Systems and software engineering - Software life cycle processes <https://www.iso.org/ru/standard/63712.html> (2021, лютий, 25)

${ }^{3}$ Файзрахманова, К. Э. (2019). Управление процессом разработки программного обеспечения (на примере анализа учета времени в процессе разработки программного обеспечения). Научно-практические исследования, 8-4(23), 101-110.
} 
для правильної ідентифікації та групування витрат, здійснених протягом життєвого циклу програмного забезпечення. Саме цим, зокрема, i обгрунтовується результати дослідження Лєщик Н.П. ${ }^{1}$ Враховуючи життєвий цикл IT-продуктів, науковець пропонує таке групування витрат за етапами:

1) дослідні інвестиційні витрати;

2) проектно-виробничі інвестиційні витрати;

3) витрати з виведення продукту на ринок;

4) маркетингові витрати після виведення продукту на ринок;

5) витрати по супроводженню продукту;

6) витрати з доопрацювання продукту;

7) можливі витрати з виведення продукту з обороту.

Причому дослідник зазначає, що витрати, які включаються до групи 1 та 2, в загальному вигляді формують собівартість IT-продукту. Проте витрати, які включені до групи 1, становлять витрати на дослідження. Відповідно до п. 9 П(С)БО 8 «Нематеріальні активи» вони повинні відображатися в складі витрат звітного періоду, в якому їх було здійснено, тобто на субрахунку 941 «Витрати на дослідження і розробки».

Якщо за результатами розробки (проектування, розробка технічного завдання, складання технологічної та планової документації) отримується актив, що відповідає умовам, визначеним в п. 7 П(С)БО 8 «Нематеріальні активи», то понесені витрати визнаються нематеріальним активом. В іншому випадку - відносяться до інших операційних витрат.

Проте слід описати інший підхід, який яскраво характеризує діяльність IT-підприємства, це створення нематеріального активу за замовленням. Облікове відображення вказаних операцій у даних учасників IT-послуг - вендорів - буде залежати від багатьох факторів, насамперед, від замовника даного програмного забезпечення та умов договору, а точніше - його предмету. Адже, якщо вендор тільки надаватиме послуги з розробки програмного забезпечення, то ці операції відображаються в обліку з використанням субрахунків 703 «Дохід від реалізації робіт і послуг» та 903 «Собівартість реалізованих робіт і послуг». Собівартість реалізованих послуг буде формуватися попередньо на рахунку 23 «Виробництво».

За умови, що предметом договору є продаж програмного продукту, який був розроблений на замовлення, в обліку вендора буде відображено формування продукту, який реалізується, на рахунку 26 «Готова продукція» 3 подальшим віднесенням сформованої собівартості на субрахунок 901 «Собівартість реалізованої готової продукції». Доходи від реалізації будуть відображені на субрахунку 701 «Дохід від реалізації готової продукції».

Для забезпечення позитивного результату процесу створення програмного забезпечення необхідним є врахування значної кількості факторів, пов'язаних з реалізацією конкретних його етапів. Їх ігнорування, недостатній рівень кваліфікації управлінського персоналу в сфері IT призводить до появи ряду проблем як об'єктивного, так і суб'єктивного характеру. Причинами відхилень від строків виконання IT-проекту можуть стати як допущені персоналом помилки в технічних та програмних засобах (внаслідок недостатнього розуміння процесу розробки програмного забезпечення), так і зміни вимог замовника. В будь-якому випадку, це здійснить вплив на розрахунок кінцевої вартості ІТ-продукту.

Як правило, основну питому вагу в собівартості розроблюваного програмного продукту складають витрати на оплату праці та відрахування на соціальні заходи, якщо працівники не вкладаються у встановлений термін, то відповідно це негативно впливає на фінансовий результат.

Для визначення суттєвості впливу та забезпечення ефективного управління розробкою програмного забезпечення необхідним $є$ надання повної інформації про вже здійсненні витрати. Накопичення інформації в даному напрямі здійснюється обліковими працівниками залежно від обраної форми організації обліку (рис. 2).

\footnotetext{
${ }^{1}$ Лещик, Н. П. (2015). Совершенствование учета инвестиционных затрат IT-компаний. Бухгалтерский учет и анализ, 12, 7-11.
} 


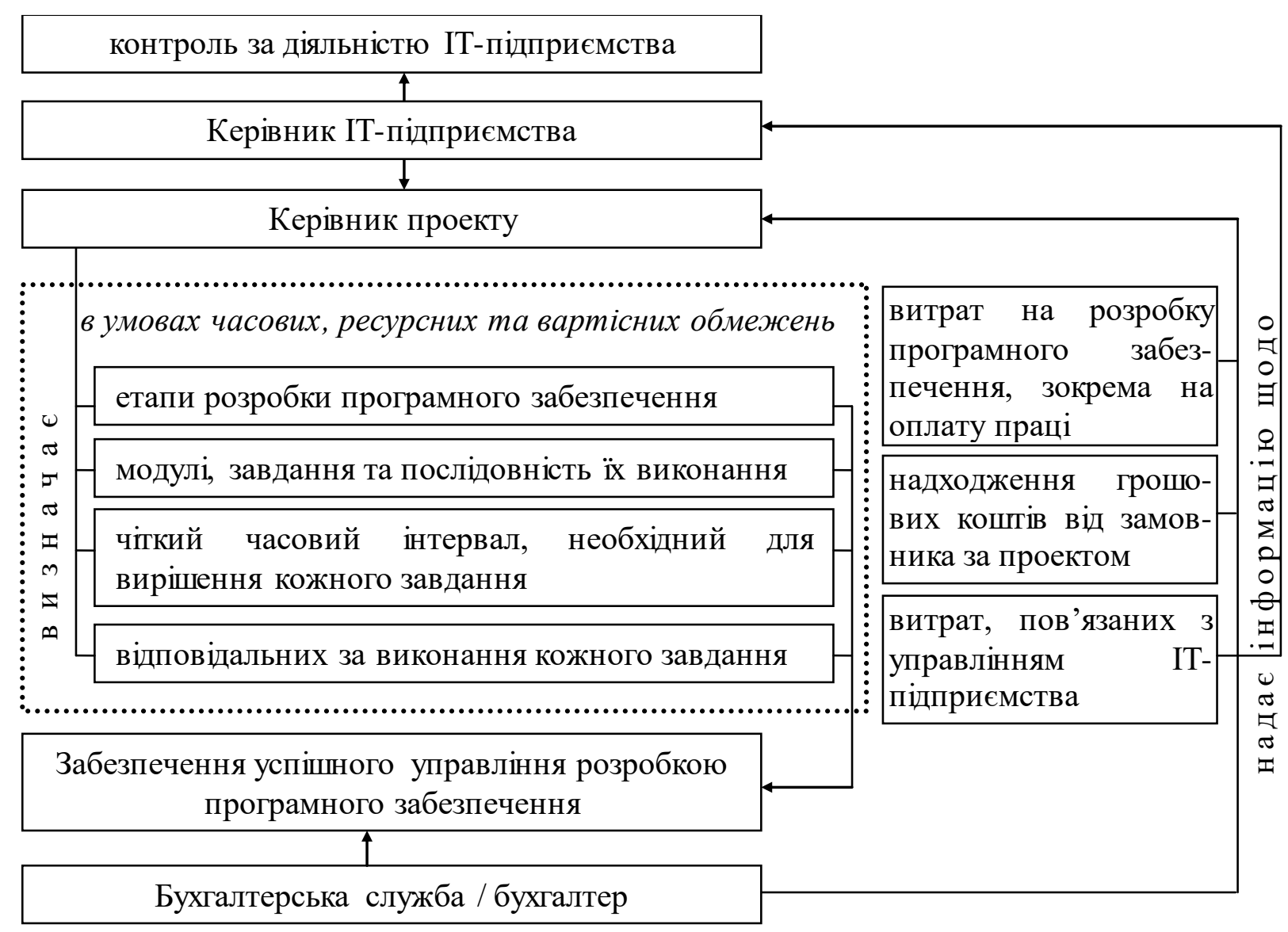

\section{Рис. 2. Процес управління розробкою програмного забезпечення на IT-підприємстві на основі облікової інформації}

\section{Джерело: розроблено автором}

Виникає об'єктивна необхідність у деталізації інформації про здійсненні витрати в ході розробки програмного забезпечення за замовленнями (IT-проектами), етапами процесу розробки. Якщо IT-підприємство невелике 3 незначною кількістю замовлень або має чіткий розподіл працівників за конкретними IT-проектами, то проблем з групуванням витрат не виникає. Коли ж ресурси (обладнання, працівники тощо) задіяні в декількох IT-проектах, то розрахунок собівартості одного проекту $є$ більш складним. Накопичені попередньо витрати на рахунку 91 «Загальновиробничі витрати» повинні бути віднесені на відповідні аналітичні рахунки, відкриті в розвиток рахунку 23 «Виробництво». Базами розподілу можуть бути:

- частка участі виробничих ресурсів в проектах (визначається менеджерами проектів) (Шаповал О.В., Тулінова Д.В. ${ }^{1}$ );

- відпрацьований час (Харітонова А. $\left.{ }^{2}\right)$.

Враховуючи, що витрати на заробітну плату розробників мають найбільшу питому вагу в структурі собівартості розроблюваного програмного забезпечення (або послуг з його розробки), вважаємо, що базою розподілу загальновиробничих витрат повинен бути час, необхідний для виконання кожного IT-проекту.

Висновки та перспективи подальших досліджень. На основі врахування особливостей діяльності визначено варіанти бухгалтерського обліку програмного забезпечення на IT-підприємстві.

\footnotetext{
${ }^{1}$ Шаповал, Е. В., Тулинова, Д. В. (2014). Особенности управленческого учета в ИТ-компаниях. Вестник ГУУ, 10 $<$ https://cyberleninka.ru/article/n/osobennosti-upravlencheskogo-ucheta-v-it-kompaniyah> (2021, березень, 25) ${ }^{2}$ Харитонова, А. (2021). Войти в IT: как вести управленческий учет, чтобы был порядок в голове и прибыль в кармане. Vc.Ru <https://vc.ru/finance/199562-voyti-v-it-kak-vesti-upravlencheskiy-uchet-chtoby-byl-poryadok-vgolove-i-pribyl-v-karmane $>$ (2021, березень, 25)
} 
Приділено основну увагу особливостям облікового відображення операціям з розробки програмного забезпечення на замовлення. Використання спеціалізованих програмних продуктів для відстеження відпрацьованого часу програмістів, побудова аналітичного обліку витрат на створення програмного забезпечення за наведеними розрізами посилить можливості обліку в напрямі обгрунтування управлінських рішень з оптимізації витрат (формування резервів витрат, обчислення вартості послуг тощо), дозволять оперативніше розраховувати окупність кожного IT-проекту, а також за умови впровадження в бухгалтерське програмне забезпечення - полегшить обробку облікових даних та побудову управлінської звітності.

\section{References:}

1. Fajzrahmanova, K. E. (2019). Upravlenie processom razrabotki programmnogo obespechenija (na primere analiza ucheta vremeni v processe razrabotki programmnogo obespechenija) [Management of the software development process (on the example of time tracking analysis in the software development process)]. Nauchno-prakticheskie issledovanija [Scientific and practical research], 8-4 (23), 101-110 [in Russian].

2. Kharitonova, A. (2021). Vojti v IT: kak vesti upravlencheskij uchet, chtoby byl porjadok v golove i pribyl v karmane [Enter IT: how to keep management accounting so that there is order in your head and profit in your pocket] $V c . R u$ <https://vc.ru/finance/199562-voyti-v-it-kak-vesti-upravlencheskiy-uchet-chtoby-byl-poryadok-v-golove-i-pribylv-karmane> (2021, March, 25). [in Russian].

3. Rezultaty analizu u «Ofisi efektyvnoho rehuliuvannia» BRDO (2021). [The results of the analysis in the «Office of Effective Regulation» (2021)]. IT-eksport u 2020. Za danymy NBU shchodo platizhnoho balansu i zovnishnoi torhivli [IT exports in 2020. According to the NBU on the balance of payments and foreign trade] <https://brdo.com.ua/wp-content/uploads/2021/02/IT-eksport-u-2020-2.pdf> (2021, March, 15). [in Ukrainian].

4. Leshhik, N. P. (2015). Sovershenstvovanie ucheta investicionnyh zatrat IT-kompanij. [Improving the accounting of investment costs of IT companies]. Buhgalterskij uchet $i$ analiz [Accounting and analysis], 12, 7-11. [in Russian].

5. Pervii, I. V. (2014). Analiz suchasnykh problem oblikovo-analitychnoho zabezpechennia stvorennia kompiuternykh prohram [Analysis of modern problems of accounting and analytical support for the creation of computer programs]. Problemy teorii ta metodolohii bukhhalterskoho obliku, kontroliu i analizu [Problems of theory and methodology of accounting, control and analysis], 3, 277-289. [in Ukrainian].

6. Shapoval, E. V., Tulinova, D. V. (2014). Osobennosti upravlencheskogo ucheta v IT-kompanijah [Features of management accounting in IT companies]. Vestnik GUU [GUU Bulletin], 10. <https://cyberleninka.ru/article/n/osobennosti-upravlencheskogo-ucheta-v-it-kompaniyah> (2021, March, 25). [in Russian].

7. ISO / IEC / IEEE 12207 (2017). Systems and software engineering - Software life cycle processes <https://www.iso.org/ru/standard/63712.html > (2021, February, 25) [in English].

8. Vendrov, A. M. (2006). Proektirovanie programmnogo obespechenija jekonomicheskih informacionnyh sistem [Software design for economic information systems]. Moscow: Finansy i statistika. [in Russian]. 